Volume 1, Issue 2 (Summer 2009)

\title{
A New Attribution for the Antwerp Anatomy Lesson of Dr. Joannes van Buyten
}

Beatrijs Wolters van der Wey

Recommended Citation:

Beatrijs Wolters van der Way, "A New Attribution for the Antwerp Anatomy Lesson of Dr. Joannes van Buyten," JHNA 1:2 (Summer 2009), DOI: 10.5092/jhna.2009.1.2.3

Available at https://jhna.org/articles/new-attribution-antwerp-anatomy-lesson-of-dr-jo-

annes-van-buyten/

Published by Historians of Netherlandish Art: https://hnanews.org/

Republication Guidelines: https://jhna.org/republication-guidelines/

Notes: This PDF is provided for reference purposes only and may not contain all the functionality or features of the original, online publication. This is a revised PDF that may contain different page numbers from the previous version. Use electronic searching to locate passages. This PDF provides paragraph numbers as well as page numbers for citation purposes.

ISSN: 1949-9833 


\section{A NEW ATTRIBUTION FOR THE ANTWERP ANATOMY LES- SON OF DR. JOANNES VAN BUYTEN}

\section{Beatrijs Wolters van der Wey}

The anatomy lesson in the Koninklijk Museum voor Schone Kunsten in Antwerp is the only known Flemish painting of this subject. Although the work has long been attributed to Huibrecht Sporckmans (1619-1690) and dated 1660, the author reattributes it to the Antwerp painter Frans Denys (1610-1670) and gives evidence for a new date of 1648.

DOl 10.5092/jhna.2009.1.2.3

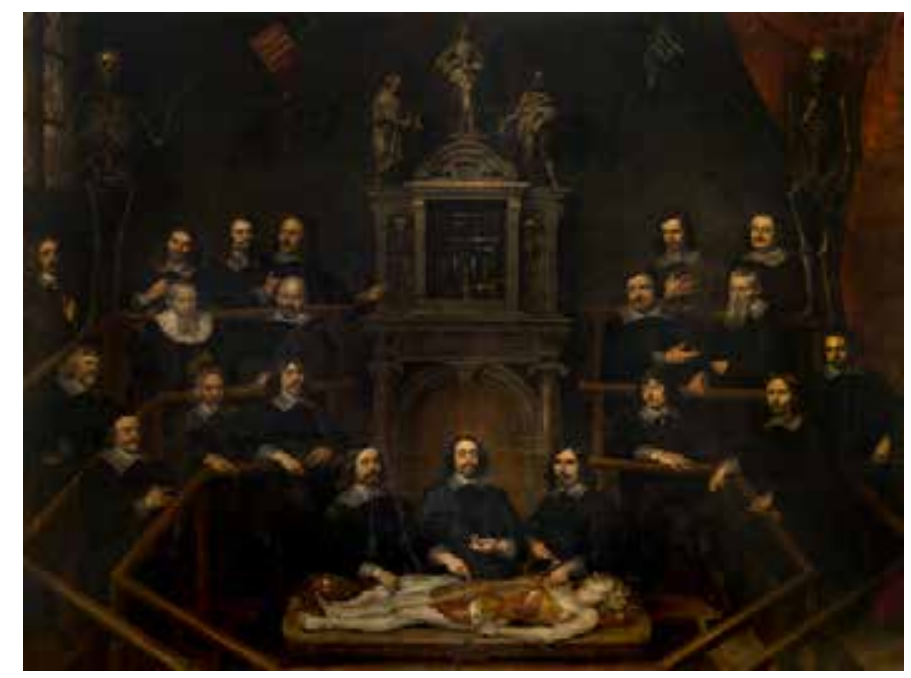

Fig. 1. Frans Denys, The Anatomy Lesson of Dr. Joannes van Buyten, 1648, oil on canvas, 345 x $482 \mathrm{~cm}$. Koninklijk Museum voor Schone Kunsten, Antwerp, inv. no. 610 (artwork in the public domain)

The Koninklijk Museum voor Schone Kunsten in Antwerp has in its possession a group portrait of surgeons attending an anatomy lesson (fig. 1). It is the only painting of this subject known in the Southern Netherlands. The work is commonly attributed to Huibrecht, or Hubert(us), Sporckmans (1619-1690) and dated 1660. Further research now provides strong evidence that the portrait was actually executed in 1648 by another Antwerp master, Frans Denys (1610-1670).

2 Since 1919, the painting (on loan from the museum) has occupied a huge wall in the staircase of 
the Geneesherenhuis (House of Physicians) at Antwerp, meeting place of the Koninklijke Geneeskundige Kring van Antwerpen (Royal Circle for Medicine of Antwerp), following its discovery by one of the association's members in the attic of the Antwerp museum. This large canvas may be associated with a 1648 contract for a painting depicting a theatrum anatomicum with portraits (Annex I). ${ }^{1}$ The published transcription of this contract has been referred to in some art-historical texts and in the database of the Rijksbureau voor Kunsthistorische Documentatie (RKD) in The Hague, but the contract was never linked to the group portrait in the Antwerp museum, given that work's attribution to Sporckmans and its dating to $1660 .{ }^{2}$ More research now provides strongevidence that the Anatomy Lesson under discussion here is actually the work ordered in 1648 from Frans Denys.

Let us first take a look at the painting itself (fig. 1). ${ }^{3}$ It consists of three pieces of canvas, joined horizontally, making up a support measuring $345 \mathrm{x} 482 \mathrm{~cm}$. Represented are seventeen participants and three (prelectors or instructors) of an anatomy subject. The room is decorated with two skeletons holding a small banner with a text memento mori: "nescis quid serus vesper vehat" (you do not know what night will bring) and "stipendium peccati $\mathrm{m}$ ors" (the wages of sin is death). To the left, can be seen a window, and to the right a red drapery. In the center background, there is a display case with surgical instruments above what appears to be a chimney, flanked by two skeletons of babies (fig. 2). Above the case stand statues of Cosmas and Damian, the patron saints of Antwerp physicians, and Mary Magdalene. ${ }^{4}$

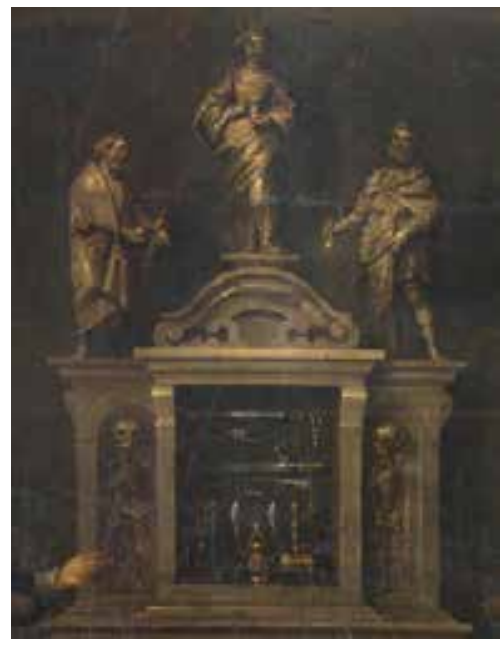

Fig. 2. Frans Denys, detail from The Anatomy Lesson of Dr. Joannes van Buyten (figure 1)

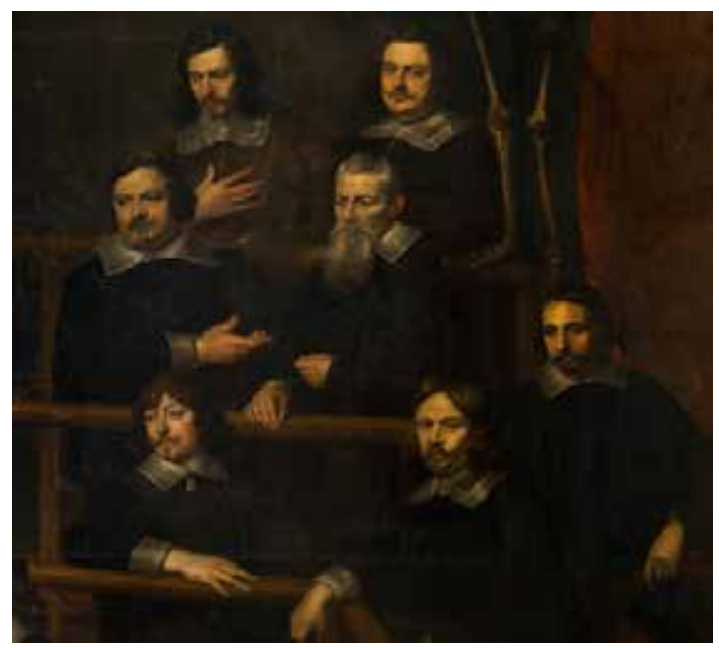

Fig. 3. Frans Denys, detail from The Anatomy Lesson of Dr. Joannes van Buyten (figure 1)

The iconography fits well with the order Frans Denys received in 1648: he promised to paint a picture of a theatrum anatomicum with nineteen portraits, including the instructors as well as "the present and former Body of Deans" of the Corporation of Surgeons. The Antwerp painting, however, includes twenty rather than nineteen figures. This may be explained by observing that one of them differs somewhat from the others: in the right group in the last row, the first man at the left is wearing a brown suit instead of a black one like his companions, and his pose indicates a certain self-confidence (fig. 3 ). The fact that he appears to bow and gesture may suggest he is the artist and the discordant figure thus a self-portrait. Alternatively, this figure might represent the gildeknaap (guild servant), rendered in a different color to distinguish him from his surgeon 
companions. $^{5}$

According to the contract, Frans Denys had to finish his painting in an extremely short period. He was given four months, from February 3 until the last day of May. He was promised $375 \mathrm{gul}$ den (guilders), a fee that was to be paid in three installments, 100 guilders in cash immediately to start the work, another 100 guilders halfway, and the remaining 175 guilders once the painting was completed. The artist could request a few extra weeks to complete his piece, but if he were not ready at the end of June, he would receive 50 guilders less than the quoted sum.

May we now suppose that the Anatomy Lesson of the Antwerp museum, corresponds to the painting ordered from Frans Denys in the 1648 contract? Or could it be that Huibrecht Sporckmans painted a second group portrait of surgeons some years later and that the earlier painting by Denys disappeared, as suggested in the above-mentioned articles?

The first reason for doubting the existence of a second group portrait arises from the very fact that the composition of a group portrait within an anatomical theater--and one with such large dimensions--is very unusual in seventeenth-century Antwerp and indeed in the whole of the Southern Netherlands. It seems unlikely, although not impossible, that only twelve years after the commission to Denys the same corporation ordered a new large group portrait. Neither the archives of the Antwerp Corporation of Surgeons nor those of the Collegium Medicum shed further light on the matter. ${ }^{6}$ Documents relevant to the years 1648 and 1660 do not reveal any reference to the group portrait by Frans Denys nor to one by Huibrecht Sporckmans. Even the agreement with Denys would not have been known had Duverger not published, in his systematic archival survey, a contract made before one of the dozens of notaries active in Antwerp at that time. $^{7}$

An additional element weakening the case for a second group portrait after twelve years is the fact that the Corporation of Surgeons experienced recurring financial problems during the seventeenth century. They were even driven to "borrow" money from the armenbusse, monies ostensibly intended as alms for the poor. ${ }^{8}$ An archival document from around 1676 denounces this abuse. ${ }^{9}$ Yet the same document reveals how even this lack of money did not prevent the deans from spending more than three thousand guilders on furniture for the adornment of their Guild Hall. ${ }^{10}$

9 Furthermore, it could be argued that the Koninklijk Museum's painting could also have been donated or executed for a minimum fee by Sporckmans, who apparently had a brother Lodewijk, or Ludovicus, who was a physician and is mentioned in the membership list of the Antwerp Collegium Medicum around 1659. ${ }^{11}$ Earlier articles that discuss the painting stress this family relationship to explain why a lesser-known artist such as Sporckmans executed the group portrait. ${ }^{12}$ These family ties in themselves are not, of course, a sufficient argument for the attribution of a painting. Indeed, one of the deans signing the 1648 contract with Frans Denys, namely Peeter van Cortbemde, also had a brother who was a painter, Balthasar van Cortbemde (1612-1663), and yet the group portrait was not ordered from him. ${ }^{13}$ Balthasar van Cortbemde was active as a painter during these years, and the only known painting from his hand--a religious scene with the parable of the good Samaritan--executed in 1647 specifically for the Corporation of Surgeons, is 
of high quality. ${ }^{14}$

10 Historical investigation undermines the attribution of the AnatomyLesson to Sporckmans. First of all, it is clear that the work did not enter the museum's collection as a painting by Sporckmans. In 1800-1810, it is listed, together with the other paintings confiscated by the French from the suppressed Antwerp corporations and centralized in the newly formed museum in the former cloister buildings of the Friars Minor, as an "anatomy lesson" by an unknown painter. ${ }^{15}$ The group portrait does not appear in the first descriptive lists and catalogues of the Antwerp museum, published between 1816 and 1851. It only features from 1857 onwards, when it is initially listed as number 485 and catalogued as a seventeenth-century picture of the Flemish school. Since 1871, it has been listed as number 610, the inventory number in use today. In an Antwerp city guide of 1874 , the painting is cited as an eighteenth-century work, probably a mistake. ${ }^{16}$

11 The first traceable mention of Sporckmans in relation to the group portrait comes two years later, in 1876, at the end of a short article about the artist's life and work by Désiré van Spilbeeck, editor of the journal De Vlaamsche School. In this account, the author refers to a large painting by Sporckmans showing an anatomy lesson. ${ }^{17}$ From his wording it is clear that he was using a secondary source. ${ }^{18}$ At that time, the picture itself was in poor condition and stored in the attic of the Antwerp museum. The painting had obviously been put aside by 1868 , the year during which it was listed by the same author in an overview of "the works of art indicated in the catalogue of the museum that are either not situated there or are not visible," but at that point it was still mentioned as being by an unknown artist. ${ }^{19}$ In his Geschiedenis der Antwerpsche schilderschool, published in 1879, Max Rooses does not refer to the Anatomy Lesson, whereas Jos van den Branden in 1883 includes it in his biography of Huibrecht Sporckmans. Could Van den Branden, assistant archivist for the city of Antwerp since 1865, have persuaded Van Spilbeeck to change his mind on the painting's attribution? For Van den Branden, though describing the work as "rolled up" in the museum's attic, was able to look at it personally. Not only does he briefly describe the composition, but he also records its extremely bad condition, while explicitly indicating that "it contains still intact sections which are beautiful." 20

12 When Dr. Alexandre de Mets rediscovered the picture in 1919, it was still rolled up in the museum's attic. The folding lines and damage to the paint and the canvas are still visible today over the whole surface of the picture, even though it was immediately lined and restored after the "discovery." This conservation treatment was the result of the efforts of the then curator of the museum, Cornette, and the financial support of the city and province of Antwerp and of the Royal Circle for Medicine. On the occasion of the $300^{\text {th }}$ anniversary of the Collegium Medicum on December 12,1922 , the painting was finally moved to its current place of residence, the House of Physicians in Antwerp. ${ }^{21}$ From that time on, the Anatomy Lesson is referred to in most publications as a painting by Huibrecht Sporckmans and dated 1660, although the catalogues of the Antwerp museum attribute it to Sporckmans for the first time only in the 1948 edition and never specify its date. $^{22}$

13 The archivist Jos van den Branden seems to have been the first to link the group portrait with the date of 1660, in his Geschiedenis der Antwerpsche schilderschool of 1883. The key argument for this dating can be found in his personal notes, the very useful "Nota's Van den Branden," which 
formed the basis for his publication and are kept in the city archives of Antwerp. The relevant note is written on a small piece of paper and, while it does not bear the painter's name, it is filed under "Sporckmans" and states quite enigmatically: "Hans Goossens large painting outside (?) in the Physicians' Hall on the Waag, March and November 1660 Nr. 494." ${ }^{23}$ The Waag, Stadswaag, or Nieuwe Waag was the public weigh-house, situated in the square of the same name, the Stadswaag, where the Corporation of Surgeons had had the use of two rooms since 1612/13. Unlike most of Van den Branden's notices, in this case the reference number ("Nr. 494") does not make sense. It appears to suggest a catalogue or an inventory number rather than a reference to an archival document, but it corresponds to neither the old nor the new numbering of the Antwerp museum. ${ }^{24}$

14 In a separate note, Van den Branden states that "the painting of Hubert Sporckmans, the anatomy lesson, is described in the museum catalogue of 1857, as a picture of an unknown master." ${ }^{25}$ What he did not record, probably because he did not read the catalogue note all the way to the end, is the very last sentence: "this picture of which the damaged signature has become illegible, carries the date of 1645, or maybe 1649." 26 Indeed, on the canvas, in the lower left corner, there are still some visible traces of what must have been the signature and, on a second register, probably the year of execution. This quote from the 1857 catalogue, citing traces of a date in the 1640s--there is no doubt that the first three digits read "164"--brings us back to the contract that Frans Denys received in 1648 for a group portrait of the Antwerp Surgeons in a theatrum anatomicum.

15 Why then in 1874, and possibly at Van den Branden's instigation, was the museum's painting attributed to Huibrecht Sporckmans? This is a question that unfortunately has to remain unanswered at this stage of research. It can only be assumed that Van den Branden or the person responsible for the attribution to Sporckmans saw some stylistic resemblances to another large signed group portrait by Sporckmans, bought in 1859 by the city of Antwerp and kept at that time in the City Hall. This work depicts twenty-four men to the left of a dramatic scene, probably "The city of Antwerp imploring the opening of the Scheldt." ${ }^{27}$

16 Frans Denys was born around 1610 in Antwerp and spent most of his life in the city. In 1632, he became a master painter and in 1641 he took on two apprentices. From 1654 on, he was active abroad, first working for the art-loving Duke Friedrich III von Holstein-Gottorf, later as court painter for Ranuccio II of Parma, and finally for Regent Isabella Clara in Mantua, where he died in $1670 .{ }^{28}$ Whereas a stylistic assessment of Huibrecht Sporckmans is difficult given the relatively small oeuvre authenticated with any certainty as by his hand, there are a larger number of paintings and engravings by Frans Denys available for comparison. ${ }^{29}$

17 Today, about twelve pictures from Denys's Antwerp period, dated between 1635 and 1653, have been traced. All of these are portraits. The earliest are two pendant portraits, signed and dated 1635, of Andries van Langenberghe and his wife Anna Zegers, identified by the coat of arms (Brussels, de Borrekens private collection in 1962). ${ }^{30}$ The same holds for the double portrait of Peter van Horne and Barbara Heylen, signed and dated 1637(Brussels, Baillet-Latour private collection in 1939; the male portrait sold in Brussels, Palais des Beaux-Arts, in 1961). ${ }^{31}$ A portrait of a clergyman, with a coat of arms and the motto "non in solo pane," now in the Kunsthistorisches Museum in Vienna, is signed by Frans Denys and dated 164(0?). ${ }^{32}$ Before 1647, the 
artist made another pair of contrefeytsels (portraits), of the painter Charles de Cauwer (master in 1609, died 1657/58) and his wife Elizabeth Vleckhamers, possibly a paternal aunt of Denys's first wife, Martina Vleckhamer(s) (married Frans in 1632, died 1647). The pictures are known from the sitters' last will of January 15, 1647, where they were bequeathed to their son Carel Francis. ${ }^{33}$ A signed family portrait, dated 1651, was sold at American Art Association in New York in 1916. ${ }^{34}$ The palace of Versailles holds the portrait, at the age of twenty-two, of François-Paulin de Brouchoven, lord of Vechel and later an alderman of Antwerp, which is signed and dated 1652 (fig. 4). ${ }^{35}$ A double portrait of a husband and wife, the man in the guise of a hunter, signed and dated 1653, was shown in 1990 at Müllendorff, an Antwerp art dealer. ${ }^{36}$ Three other authenticated paintings contain the portraits of artist colleagues: a portrait of the painter Jan van Balen (1611-1654) was sold in 1895 at Lepke (Berlin), a signed picture of an unidentified architect, age forty-two, appeared in 1914 in Paris (Galerie Georges Petit), and an oil sketch of the still-life painter Alexander Adriaenssen (1587-1661) was shown in Amsterdam in 1932. The latter is a mirror image of the engraving by Antony van der Does (1609-1680) included in Anthony van Dyck's Iconographia, of which the first state was signed by Denys. ${ }^{37}$

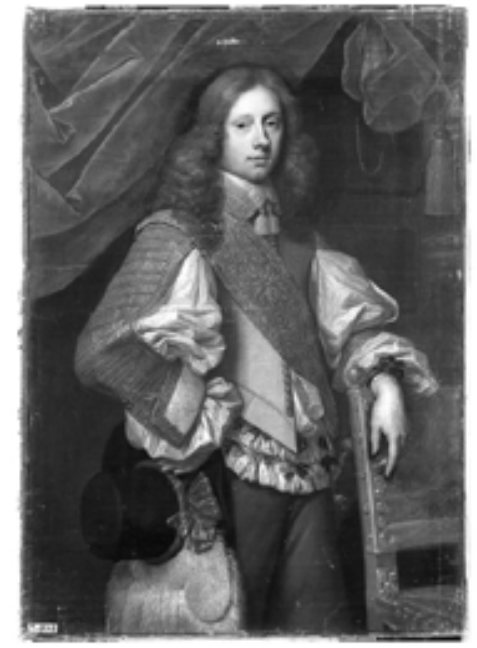

Fig. 4. Frans Denys, François-Paulin de Brouchoven, Lord of Vechel, 1652, oil on canvas, $116 \times 84 \mathrm{~cm}$. Musée national du Château de Versailles, inv. no. M3494 (artwork in the public domain)

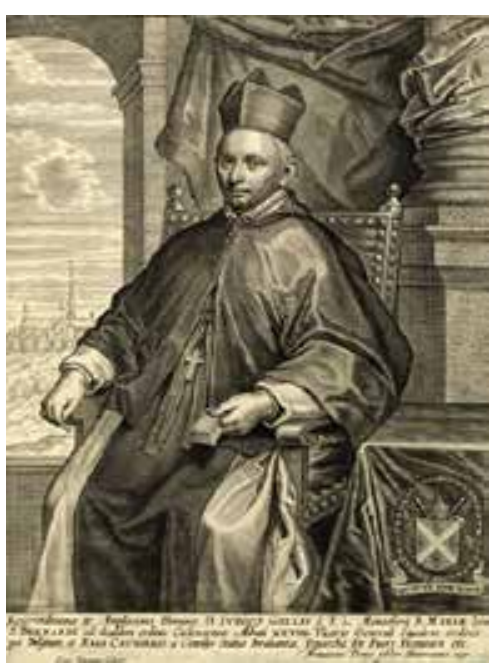

Fig. 5. Conrad Wauman, after Frans Denys, Jodocus Gilles, Abbot of the Antwerp Abbey of Saint Bernard and Member of the Council of Brabant, engraving, folio. Koninklijke Bibliotheek van België, Albertina, Brussels, inv. no. S. II 80559 (artwork in the public domain)

Hollstein mentions another ten portrait prints under Denys's name, some of which may date to after 1654: one depicts a philosopher and one depicts Guilielmus Marcquis, son of the famous Lazarus Marcquis, a physician in Antwerp, seven are members of the aristocracy, and a last one is the abbot of the important Antwerp Abbey of Saint Bernard, who was also a member of the council of Brabant (fig. 5). ${ }^{38}$ This overview makes clear that Frans Denys was a highly appreciated portrait painter in his time. Aristocrats ordered most of his paintings, although several were commissioned by fellow townsmen of the middle class. A large number of these portraits were engraved, some of them probably intended for this medium.

19 Despite his success, Denys was not particularly innovative in terms of style. During his entire Antwerp career, he maintained a rather wooden manner of rendering his sitters, mostly halflength or down to the knees, and in some engravings only the bust. ${ }^{39}$ Subjects either sit or stand 
upright and are always in a more or less three-quarter position. Neither in individual nor in double portraits is there any dynamic movement: the sitters are represented in static poses. Only the rendering of the hands brings variation here and there. Hands are often a little twisted, with the index or other fingers wide apart. This gesture, a particular characteristic of Denys's paintings, does not appear to carry meaning. The setting is kept rather sober, while all attention goes to the execution of the faces and representation of dress, the latter sometimes quite sumptuous. As to the facial features, they are accurate but rather sharp, emphasizing bags under relatively wide eyes, and with a pronounced nose and tight lips. The portraits hardly show any individual expression and the sitters stare straight ahead, impassive and serious.

20 Probably because Denys's oeuvre consists exclusively of portraits, as far as is known, and because many of his patrons belonged to the aristocracy, he is sometimes considered a follower of Anthony van Dyck (1599-1641). ${ }^{40}$ Van den Branden called him a painter as talented as the other Antwerp portrait specialist, Justus Sustermans (1597-1681), who, like Van Dyck, also emigrated, but noted, with regret, that Denys was almost forgotten. ${ }^{41}$ This is no doubt due to his more traditional and severe style.

21 A study of the Anatomy Lesson presents an ideal opportunity to get reacquainted with the artist. Indeed, the group portrait is wholly representative of Denys's typical manner of painting, displaying the same treatment of the faces and lack of expression that characterizes the artist's signed portraits. Another similarity with Denys's painting style is the overall sober execution. There are no more attributes than strictly necessary to characterize the subject, and the general palette is brown, gray, and black, except for the red drapery, red tones in the anatomy subject, two small banners in red and blue, and a more vivid blue and white behind the window. Moreover, the individuals are grouped together in a very static manner. There is no inner compositional coherence apart from the structuring of the group in the staged setting of the anatomical theater. The surgeons do not appear to be paying much attention to the dissection in progress. They are posed as if their only concern was to be recognized for their portraits, and they mostly gaze outward, with no real focus. The only indication of any differentiation among the surgeons can be seen in the gesticulation of their hands, again a typical feature in Denys's oeuvre. This lack of compositional coherence, with a total absence of dynamic movement, is perhaps understandable in the case of a painter who had never before--and apparently never afterwards--been faced with a task of this scale. It can be assumed that the artist decided upon the format of the painting in agreement with his clients, the deans of the corporation, in the light of particular constraints. Nineteen--in fact twenty--portraits had to be included in the setting of the anatomical theater, and the painting had to fit within the space available in the room where it was destined to hang.

22 Together with these stylistic observations, which favor an attribution of the Antwerp group portrait to Frans Denys, there is another argument that supports an earlier dating of around 1648 rather than 1660, which makes it possible to link the painting with the contract concluded with Denys.

23 The chief praelector, placed in the mid-foreground (fig. 6), has long been identified as Joannes van Buyten (1612-1683), who became stadsdokter (physician in city service) in Antwerp in 1642 and was appointed professor in anatomy by the Antwerp Collegium Medicum in 1646. His appear 


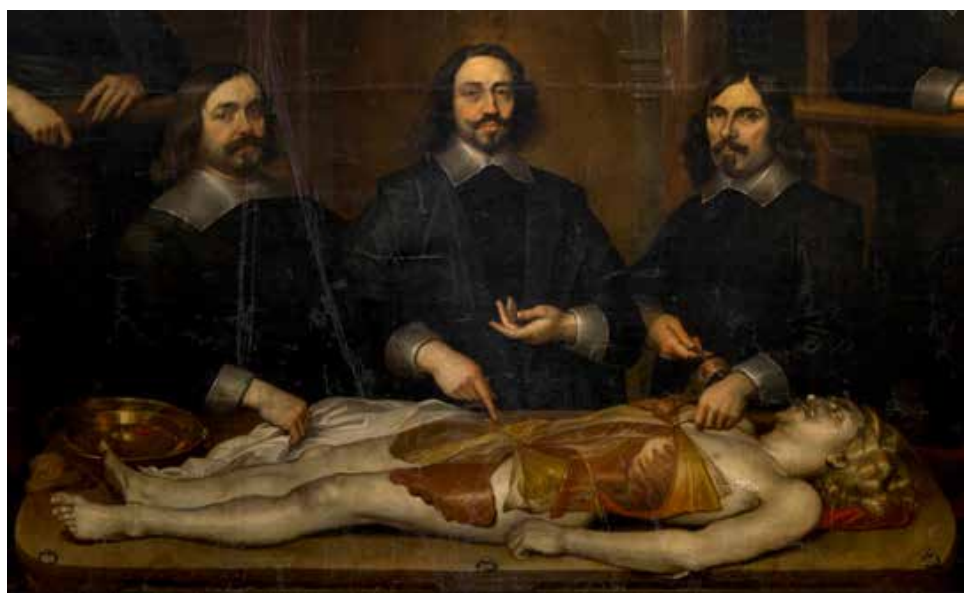

Fig. 6. Frans Denys, detail from The Anatomy Lesson of Dr. Joannes van Buyten (figure 1)

ance in the group portrait can be compared to that in an individual portrait of 1674 executed by Charles Emmanuel Biset (1633-1713). This portrait (fig. 7) was engraved by Arnold van Westerhout (1651-1725) and included in Theatrum fungorum oft Toneel der Campernolien (Antwerp, 1675) by the priest and botanist Frans van Sterbeeck (1631-1693). ${ }^{42}$ In his last will and testament, van Buyten refers to "the portraits and the Conversation [probably a Conversation piece] of Biseth." ${ }^{43}$ Biset represented the anatomist, who was then sixty-two, as an old man, with a wrinkled face and long white hair. This aged appearance stands in stark contrast to his youthful representation in the Anatomy Lesson. It is therefore plausible that he was first portrayed at the age of thirty-six, twenty-six years earlier than the print, in 1648, rather than only fourteen years before, in 1660. Furthermore, in 1648, Joannes van Buyten, after two years of experience as praelector or professor in surgery and anatomy, took steps to improve the discipline in surgery classes, including those on anatomy. In the spring of 1648, together with the deans and the aldermen of the corporation, he drew up the rules of courses for the students in surgery. Van Buyten presented their draft to the mayor and aldermen of Antwerp in a letter of April 22, 1648, and the rules were confirmed by the Maendagsche Raedt in July. ${ }^{44}$ All these facts show that Joannes van Buyten was a committed professional at an early age and that in 1648, no less than in 1660, his prominent place in the Anatomy Lesson would have been appropriate.

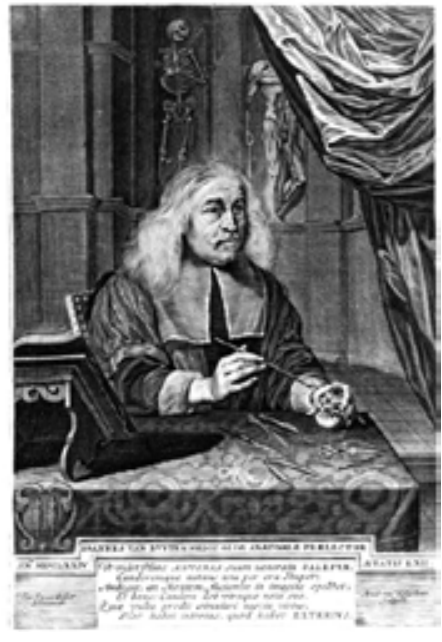

Fig. 7. Arnold van Westerhout, after Charles Emmanuel Biset, loannes van Buyten, 1674, engraving, 225 × 148 mm. Koninklijke Bibliotheek van België, Albertina, Brussels, inv. no. S. II 23820 (artwork in the public domain)

24 Perhaps, then, the commissioning of a group portrait was related to the efforts of the corporation 
in 1648 to improve the organization and the conditions of the apprenticeship and practice of the surgeons. The commissioned painting could be interpreted as a pictorial assertion of the spirit of service and responsibility that inspired the board members of the corporation during this period. Indeed, the contract with Frans Denys specified that, besides the instructors, the present and former board of deans ("de dienende en de oude eed") of the Corporation of Surgeons should be portrayed. Thus no ordinary surgeon members were to be represented. Nor was this the group portrait of the Collegium Medicum, an association founded in 1620 and separate from the Corporation of Surgeons, which had been founded in 1450. The Collegium Medicum acted as a monitoring body consisting of seven members, set up to guarantee the rights of doctors and patients and to ensure the quality of professional practice by physicians, pharmacists, and midwives. ${ }^{45}$ Furthermore, the dress and hairstyles of the surgeons favor an earlier dating of the group portrait, for they would not have been worn much later than $1648 .{ }^{46}$

25 One of the instructors on the left side of the Anatomy Lesson has been repeatedly identified as Michiel Boudewijns (1622-1681). ${ }^{47}$ This identification is questionable if the Anatomy Lesson is redated to 1648. Boudewijns first studied philosophy and theology and then pursued another three years of medicine in Leuven. Only in 1662 was he appointed stadsdokter of Antwerp, succeeding Van Buyten as professor of surgery. ${ }^{48}$ Furthermore, a comparison of Boudewijns's supposed portrait in the Antwerp Anatomy Lesson with an individual portrait of him at the age of forty-two, executed by Abraham van Diepenbeeck (1596-1675) in 1664 and engraved by Petrus Clouwet (1629-1670), makes it unlikely this is the same man. ${ }^{49}$

26 Besides Joannes van Buyten, two other surgeons can now be identified as being included in the Anatomy Lesson, although their portraits cannot be localized within the group: the Deans Peeter van Cortbemde and Martin Marcany (Mariconi/Macaigne), who practiced in 1647-48 and signed the contract with Frans Denys. ${ }^{50}$

27 Taking into account historical, stylistic, and iconographical considerations, as well as the date of 1640s given for the painting in the 1857 museum catalogue, we thus conclude that the Antwerp Anatomy Lesson might well be the painting executed by Frans Denys in 1648. Clearly the Antwerp surgeons, when they commissioned Denys to paint their group portrait, were aware of the artist's reputation: he was one of Antwerp's well-known portraitists and still active in the city at that time. (His excellent reputation would also explain the short time period negotiated for the execution of the work.) The result is both an art historical as well as a medical-historical record of great interest and importance.

28 From an art-historical viewpoint, it is the only example of a large group portrait in the form of an anatomy lesson in the Southern Netherlands in the seventeenth and eighteenth centuries. The only comparisons are two seventeenth-century group portraits of surgeons in Bruges. The earlier one of these, dated 1677 and painted by Filips Bernaerts (active in Bruges between 1648-1677), shows the surgeons in a meeting around a table. The second, dated 1679 , portrays a dissection on a much smaller size, with only four physicians taking part in the activity. ${ }^{51}$ This lack of a tradition of painted anatomy lessons contrasts sharply with the situation in the Northern Netherlands. Especially in Delft and Amsterdam, anatomy lessons were executed throughout the seventeenth and eighteenth centuries. The first group portrait of surgeons explicitly situated in an anatomical 
theater was painted in Delft in 1617 by Michiel van Mierevelt (1567-1641) (fig. 8) ${ }^{52}$ Another

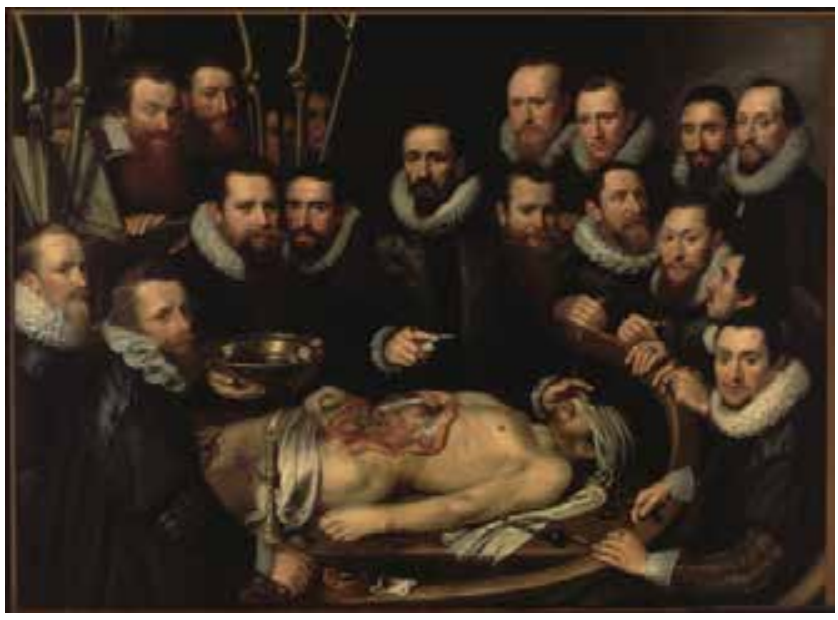

Fig. 8. Michiel van Mierevelt, The Anatomy Lesson of Dr. Willem van der Meer, 1617, oil on canvas, 144 x $198 \mathrm{~cm}$. Delft, Stedelijk Museum Het Prinsenhof, inv. no. B112 (on loan from the Oude en Nieuwe Gasthuis, Delft) (artwork in the public domain)

famous example is, of course, Rembrandt's Anatomy Lesson of Dr. Nicolaes Tulp (1632), which, although not rendered in the space of a theater, is the first painting where the prelector is actually engaged in the process of dissection..$^{53}$ At this stage, there is no indication that the Antwerp surgeons or the painter Denys were personally familiar with those northern anatomy lessons nor therefore found in them a source of inspiration for the Antwerp composition.

29 For the history of medicine, Denys's painting is a major statement of the practice of anatomy lessons in the context of surgery apprenticeship in Antwerp. The existence of anatomy lessons is known from archival documents and medical-historical studies. ${ }^{54}$ But these publications are rather vague about the Antwerp anatomical theater. It was installed by Dr. Lazarus Marcquis (15741647 ) in a room that he obtained from the city in the above-mentioned Stadswaagfollowing a request of $1612 .{ }^{55}$ Lazarus Marcquis had seen the benefits of such a theatrum anatomicum during his studies in Leiden (1594) and Padua (1597), where he must have attended demonstrations in brand new theaters constructed, respectively, in 1593 and 1594 (fig. 9). ${ }^{56}$

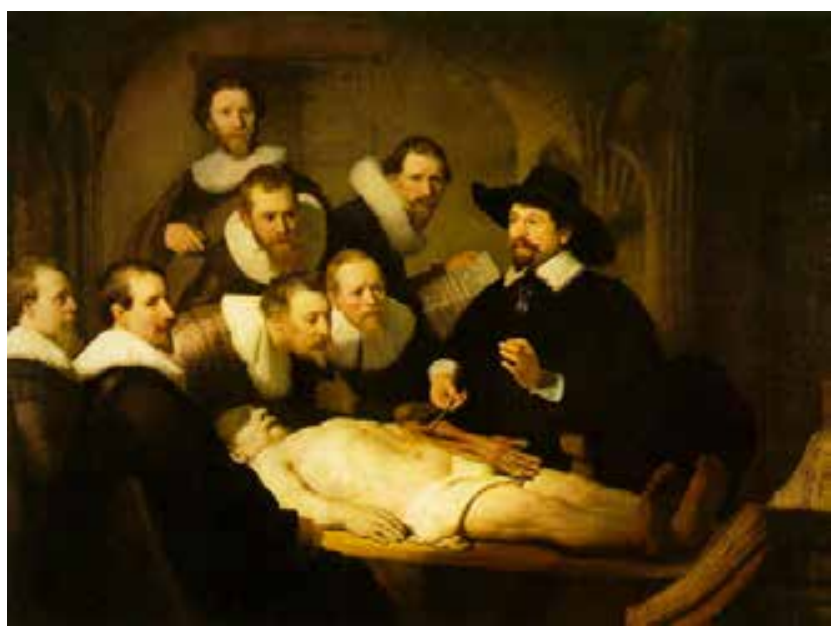

Fig. 9. Rembrandt, Anatomy Lesson of Dr. Nicolaes Tulp, 1632 , oil on canvas, $169.5 \times 216.5 \mathrm{~cm}$. Mauritshuis, The Hague, inv. no. 146 (artwork in the public domain)

From his 1612 request, it is not clear how the theater was set up, except for the mention of human and animal skeletons. Nevertheless, at the end of his life, in two requests to the city magistrate, which include a survey of his multiple activities as doctor in the service of the city, Marcquis 
described more explicitly the ana tomy theater, calling it "the room with the theater" that he had "adorned with different skeletons" and the "anatomy room in the Nieuwe Waag he had adapted for the public demonstration of the art of anatomy." ${ }^{\prime 7}$ Moreover, the rules for the surgery classes drawn up by Joannes van Buyten in 1648 mention the "anatomical room or theater." ${ }^{2}$ We may therefore assume that Denys's painting is a fairly true-to-life representation of the Antwerp anatomical room of 1612 and that it took the form of an octagon.

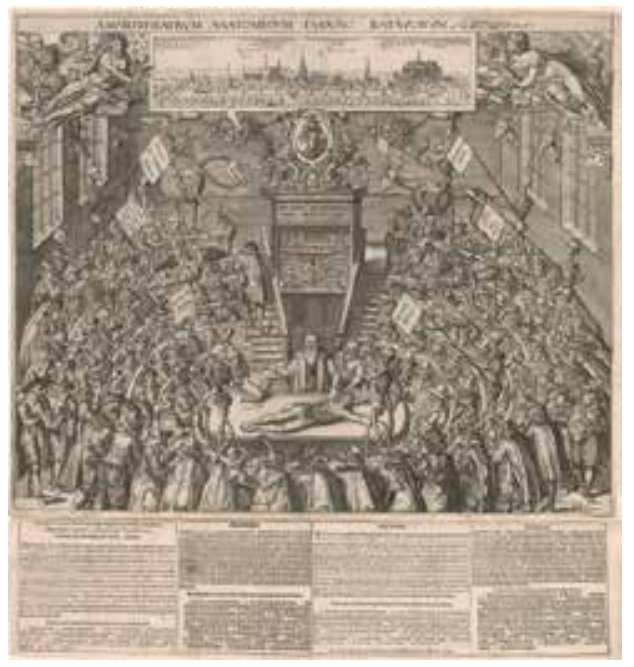

Fig. 10. Bartholomeus Dolendo after Jan Cornelisz Woudanus, The anatomical theater in Leiden, 1609, engraving, 466 × 558 mm. Rijksmuseum, Rijksprentenkabinet, Amsterdam, inv. no. RP-P-0B-98271(artwork in the public domain)

31 In an irony of fate, the 1874 catalogue of the Antwerp museum includes an introductory note on the painter Jacob Denys (1644-1708/33), which gives his father Frans high praise. Frans Denys is commended for his "excellence as a portrait painter, almost forgotten nowadays, who deserves an eminent place among the master painters of the seventeenth century; he is very close to the great models of this remarkable period." ${ }^{59}$ The museum committee did not realize that their attic, a few meters away, hid an authentic painting by the artist, unique in its genre as an Antwerp "anatomy lesson," and one of the most remarkable works by Frans Denys.

\section{Appendix}

February 3, 1648 - Contract between the practicing Deans of the Antwerp Surgeons' Corporation, Peeter van Cortbemde and Martin Mariconi, and the painter Fran çois Denys for a Theatrum anatomicum with nineteen portraits.

Syn tsaemen overcommen ende geaccordeert Srs. Peeter Cortbemde ende martinus maricony beyde dienende dekens van het Chirurgijns ambacht binnen dese stadt ter eenre, ende Sr. francoijs de Nijs constschilder al hier ter andere syden, ende dat inde manieren naer volgende, te weten dat den voornoemde Sr francoijs de nijs geloeft ende sich verobligeert heeft tusschen heden date deses ende ultima maij toecomende te maecken wel ende loffelyck een stuck schilderye ende daerinne te schilderen Theatrum anatomicum met negenthien contrefeytsels soo vande Prelecteurs als vande dienenden ende ouden eet van het voors. Chirurgyns ambacht, ten pryse ende voorde somme van drijehondert vijventseventich guldens eens, die beyde de voornoemde twee dienende dekens geloeft hebben ende geloven mits desen aende voornoemde sr francoys de nijs op te leggen ende te betaelen te weten Eenhondert guldens daeraff contant, Andere hondert 
guldens ten halven van het werck, ende de resterende hondert vijventseventich guldens soo haest t voors. stuck schilderye volcomentlyck sal wesen voldaen. Is voorders geconditioneert door de voors. dienende dekens aende voors. somme van drijehondert vyventseventich guldens sullen mogen cortten de somme van vyftich guldens eens ingevalle t voors. stuck schilderije in een maendt naer date van voors. ultima maij naestvolgende nijet volcomentlyck en is voldaen, welcke vyftich guldens den voornoemde sr. francoijs indien gevalle sal verbeuren, Toirconden hebben de voors. Contractanten dese onderteckent In Antwerpen desen derden februarij a ${ }^{\circ} 1648$.

[getekend:]

francoijs Denijs

Peeter van Cortbempde

Martin Macaigne ${ }^{60}$

\section{Acknowledgements}

The author is very grateful to her colleague Dr. Christina Currie (Koninklijk Instituut voor het Kunstpatriomonium, Brussels) for her help in writing the English version of this text.

Beatrijs Wolters van der Wey is a graduate of the Katholieke Universiteit van Leuven in Classical Philology and the History of Art. She is currently earning the Ph.D. at the Katholieke Universiteit van Leuven, conducting her research in collaboration with the Koninklijk Instituut voor het Kunstpatrimonium ( Brussels)as part of the research program "Stimulering van het onderzoek in de federale wetenschappelijke instellingen" sponsored by the Belgian government. Previously, she has published on seventeenthcentury Flemish painting.

\section{List of Illustrations}

Fig. 1. Frans Denys, The Anatomy Lesson of Dr. Joannes van Buyten, 1648, oil on canvas, $345 \mathrm{x}$ $482 \mathrm{~cm}$. Koninklijk Museum voor Schone Kunsten, Antwerp, inv. no. 610 (artwork in the public domain)

Fig. 2. Frans Denys, detail from The Anatomy Lesson of Dr. Joannes van Buyten (figure 1)

Fig. 3. Frans Denys, detail from The Anatomy Lesson of Dr. Joannes van Buyten (figure 1)

Fig. 4. Frans Denys, François-Paulin de Brouchoven, Lord of Vechel, 1652, oil on canvas, 116 x 84 cm. Musée national du Château de Versailles, inv. no. M3494 (artwork in the public domain)

Fig. 5. Conrad Wauman, after Frans Denys, Jodocus Gilles, Abbot of the Antwerp Abbey of Saint Bernard and Member of the Council of Brabant, engraving, folio. Koninklijke Bibliotheek van België, Albertina, Brussels, inv. no. S. II 80559 (artwork in the public domain)

Fig. 6. Frans Denys, detail from The Anatomy Lesson of Dr. Joannes van Buyten (figure 1)

Fig. 7. Arnold van Westerhout, after Charles Emmanuel Biset, Ioannes van Buyten, 1674, engraving, 225 x 148 mm. Koninklijke Bibliotheek van België, Albertina, Brussels, inv. no. S. II 23820 
(artwork in the public domain)

Fig. 8. Michiel van Mierevelt, The Anatomy Lesson of Dr. Willem van der Meer, 1617, oil on canvas, 144 x $198 \mathrm{~cm}$. Stedelijk Museum Het Prinsenhof, Delft, inv. no. B112 (on loan from the Oude en Nieuwe Gasthuis, Delft) (artwork in the public domain)

Fig. 9. Rembrandt, Anatomy Lesson of Dr. Nicolaes Tulp, 1632, oil on canvas, 169.5 x $216.5 \mathrm{~cm}$. Mauritshuis, The Hague, inv. no. 146 (artwork in the public domain)

Fig. 10. Bartholomeus Dolendo after Jan Cornelisz Woudanus, The anatomical theater in Leiden, 1609, engraving, 466 x 558 mm. Rijksmuseum, Rijksprentenkabinet, Amsterdam, inv. no. RP-POB-98271(artwork in the public domain)

${ }^{1}$ Erik Duverger, Antwerpse kunstinventarissen uit de zeventiende eeuw, Fontes Historiae Artis neerlandicae: Bronnen voor de kunstgeschiedenis van de Nederlanden (Brussels: Koninklijke Academie voor Wetenschappen, Letteren en Schone Kunsten van België,1991),5:415-16.

${ }^{2}$ See Katlijne Van der Stighelen, "Das Porträt zwischen 1550 und 1650: Die Emanzipation eines Genres," in Von Bruegel bis Rubens: Das goldene Jahrhundert der flämischen Malerei, exh. cat., ed. Ekkehard Mai and Hans Vlieghe (Cologne and Vienna, 1992/93), 182-70; Hans Vlieghe, Flemish Art and Architecture 1585-1700 (New Haven and London: Yale University Press, 1998), 139; Allgemeines Künstler-Lexikon (Munich and Leipzig: K. G. Saur, 2000), 26:190 (as a "lost" painting); these authors, as well as the RKD database, mention the contract while discussing Frans Denys. See also the RKD website for the many different notations of the artist's name. ${ }^{3}$ Koninklijk Museum voor Schone Kunsten Antwerpen: Catalogus Schilderkunst Oude Meesters (Antwerp: Koninklijk Museum voor Schone Kunsten, 1988), 353, no. 610.

${ }^{4}$ On the patron saints of the Antwerp Corporation of Surgeons, see Nora de Poorter, "De kunstwerken van het Antwerpse barbiers- en chirurgijnsambacht," in Liber memorialis: 350 jaar Collegium Medicum Antverpiense, 25 jaar Geneeskundige Dagen van Antwerpen (Antwerp, 1970), 129. ${ }^{5}$ The distinction in costume color is significant enough to suppose that the man rendered in brown is not a surgeon like the others; for the meaning of black clothing as an expression of standing and rank in society in seventeenth-century Holland and, by extension, in Antwerp, see Irene Groeneweg, "Regenten in het zwart: vroom en deftig?", Nederlands Kunsthistorisch Jaarboek 46 (1995): 199-251. Dutch painting of the Golden Age includes other examples of artists inserting their portraits in scenes of anatomical lectures or activities; see Norbert Middelkoop and Jeroen Jurjens, "Kunsthistorische aspecten van de vier Delftse anatomische lessen," in De snijkunst verbeeld: Delftse anatomische lessen nader belicht, ed. Hans Houtzager and Michiel Jonker (Zwolle: Waanders, 2002), 71-74.

${ }^{6}$ SAA (Stadsarchief Antwerpen), GA (Gilden en Ambachten), Barbiers en Chirurgijns (Barbers and Surgeons), GA 4077 (1454-1787), GA 4080 (1615-1723); Collegium Medicum, GA 4513 ([1499]-18 ${ }^{\text {th }}$ century), GA 4514 (17 $17^{\text {th }}-18^{\text {th }}$ century).

${ }^{7}$ In this case, it was notary Jan Baptist Colijns, see SAA, N 562, f. 39v.

${ }^{8}$ SAA, GA 4077, ff. 51-53, contains a copy of all the expenses realized with money for the poor 
between 1622 and 1675.)

${ }^{9}$ SAA, GA 4077, ff. 46-49 v.

${ }^{10}$ SAA, GA 4077, f. 47.

${ }^{11}$ Jean-Pierre Tricot, "De Les in de Ontleedkunde van Antwerpen (1660): Hubertus Sporckmans (1619-1690)," in Geneeskunde rond Rubens, exh. cat. (Antwerp: Mercurius, 1977), 71.

${ }^{12}$ See, for instance, De Poorter, "De kunstwerken," 34, where she supposes financial reasons for the choice of a member's brother as the artist.

${ }^{13}$ See Alexandre de Mets, Iconographie médicale anversoise (Antwerp: Buschmann, 1929), 9 and 17.

${ }^{14}$ Now in the Koninklijk Museum voor Schone Kunsten in Antwerp, inv. no. 370; oil on canvas, 199 x $245 \mathrm{~cm}$; signed and dated.

${ }^{15}$ Published by Ch. Piot, Rapport à Mr. le Ministre de l'Intérieur sur les tableaux enlevés à la Belgique en 1794 et restitués en 1815 (Brussels, 1883; repr., Algemeen Rijksarchief en Rijksarchief in de Provinciën, 1996), 105, no. 485: "No du Catalogue du musée: 485. Provenance: Corporation des chirurgiens, à Anvers. Sujets et Auteur: Leçon d'anatomie; par un inconnu." Here it should be noted that the reference in De Poorter, "De kunstwerken," 124, to Piot's publication, as if the Anatomy Lesson was listed there with the name Hubert Sporckmans, is not correct.

${ }^{16} \mathrm{~J}$. B. van Mol, Anvers [Guide]: Histoire, Institutions, Description des Monuments et Oeuvres-d'Art (Antwerp, [1874]), 210, no. 610.

${ }^{17}$ Désiré van Spilbeeck, “Hubertus Sporckmans,” De Vlaamsche School 22 (1876): 191.

18 "Op den zolder van het Antwerpsch museum schijnt een groot stuk, door Sporckmans geschilderd, in slechten staat van onderhoud te berusten, eene Les van ontleedkunde voorstellende."

${ }^{19}$ Désiré van Spilbeeck, “Toestand van het Antwerpsch museum, in den zomer van 1868," De Vlaamsche School (1868): 202, no. 485.

${ }^{20}$ Jos van den Branden, Geschiedenis der Antwerpsche schilderschool (Antwerp: Buschmann, 1883), vol. 2, 443: "van 's meesters [Sporckmans'] werken...eene Les van Ontleedkunde, welke op den zolder van ons museum ligt opgerold. Dit uitgestrekt tafereel komt voort van onze Chirurgijns-Kamer, voor welke het ten jare 1660 werd geschilderd. Alhoewel het reeds in deerniswaardigen toestand verkeert, bevat het nog gave deelen die prachtig zijn."

${ }^{21}$ Joseph Tricot-Royer, Lamphithéâtre anatomique d'Anvers en 1660 (Antwerp: De Vlijt, 1923), 3; A. de Mets, Iconographie médicale anversoise, 9.

${ }^{22}$ The earliest articles are from 1923: Joseph Tricot-Royer, L'amphithéâtre anatomique, and Joseph Tricot-Royer, "La Leçon d'Anatomie d'Anvers," Bulletijn der Belgische vereeniging voor Geschiedenis der Geneeskunde 1 (1923): 40-50. In the museum catalogues of 1905, 1911, and 1921, the number 610 is omitted; see for instance Beschrijvend catalogus: Oude Meesters; Koninklijk Muzeum voor Schoone Kunsten (Antwerp: Boucherij, 1905), vol. 1.

${ }^{23}$ Hans Goossens groote schildery buiten (?) op de Kamer van de Doctoors boven de wage meert en november 1660 Nr. 494; see SAA, Nota's Van den Branden, PK (Privilegiekamer) 3579. With thanks to Dr. Natasja Peeters, who is familiar with Van den Branden's handwriting, for verifying the transcription and suggesting some interpretations.

${ }^{24}$ References by Van den Branden to a notarial act begin mostly with "Not." and include the name of the notary and the year; the SAA was checked for a notarial document with inventory number N 494, without success.

${ }^{25}$ SAA, Nota's Van den Branden, PK 3579: "De schilderij van Huibrecht Sporckmans de les van ontleedkunde in den catalogue du musée d'anvers 1857, p. 355 beschreven als tafereel van eenen 
onbekenden meesters."

${ }^{26}$ Catalogue du Musée d'Anvers, ed. Le Conseil d'Administration de l'Académie royale des BeauxArts (Antwerp: Buschmann, 1857), 356.

${ }^{27}$ The painting has been in the storage depot of the Antwerp museum since 1890; see Koninklijk Museum voor Schone Kunsten Antwerpen (1988), 353, no. 720; oil on canvas, 282 x $732 \mathrm{~cm}$.

Described by Van den Branden, Antwerpsche schilderschool, 2:442-43, and situated in 1677 on the basis of a date that, according to him, disappeared as a result of a conservation treatment. ${ }^{28}$ Allgemeines Künstler-Lexikon, 26:190-91. The artist is not to be confused with the painter of the same name who worked in Ypres at the end of the sixteenth and the beginning of the seventeenth century; see A. Deschrevel, Schilderwerken van de Pseudo-Karel van Ieper (Frans Denys ?) en zijn school (Ieper, 1962).

${ }^{29}$ For Huibrecht Sporckmans, the authorship of only about three known paintings, one of them the group portrait bought in 1859 by the city of Antwerp, is supported by a signature or archival data.

${ }^{30}$ Reproduced in S. Speth-Holterhoff, “Un portraitiste oublié: Frans Denys," Le cahier des Arts (June 1962): 2772-73.

${ }^{31}$ Speth-Holterhoff, "Un portraitiste oublié," no reproduction.

${ }^{32}$ Die Gemäldegalerie des Kunsthistorischen Museums in Wien: Verzeichnis der Gemälde (Vienna, 1991), 49, figure T. 424.

${ }^{33}$ Erik Duverger, Antwerpse kunstinventarissen, 5:376.) (Sale Blakeslee, March 6, 1916, no. 42.

${ }^{34}$ Sale Blakeslee, March 6, 1916, no. 42.

${ }^{35}$ Musée national du Château de Versailles: Les peintures (Paris, 1995), 1:252.

${ }^{36}$ Data and reproduction published in the Diary of Antwerp Antique Dealers of 1990; E. Müllendorff, Leopoldstraat 2, Antwerp. The painting is mentioned, erroneously as dated 1655, in Allgemeines Künstler-Lexikon, 26:191, on the basis of information published earlier in Katlijne Van der Stighelen, “Das Porträt zwischen 1550 und 1650," 182-70.

${ }^{37}$ See, respectively, Ulrich Thieme and Felix Becker, Allgemeines Lexikon der bildenden Künstler von der Antike bis zur Gegenwart (Leipzig: Verlag von E. A. Seemann, 1913), 9:84; Sale Paul Delaroff, Paris, Galerie Georges Petit, April 23-24, 1914, no. 23; notes and photograph by Ludwig Burchard, at the Rubenianum, Antwerp.

${ }^{38}$ F. W. H. Hollstein, Dutch and Flemish Etchings Engravings and Woodcuts ca. 1450-1700 (Amsterdam: Menno Hertzberger, n.d.), 5:235.

${ }^{39}$ Of the individual three-quarter-length portraits for which we know the size, one measures $116 \mathrm{x}$ $84 \mathrm{~cm}$ (Lord François-Paulin de Brouchoven, at Versailles), the other 137 x $113 \mathrm{~cm}$ (the clergyman, in Vienna). The family portrait of 1651, representing the parents and a little child down to the knees, measures 124.5 x $167.6 \mathrm{~cm}$.

${ }^{40}$ See for instance Thieme-Becker, 9:84. Note that Denys does not figure amongst the apprentices or followers of Anthony van Dyck in Alfred Michiels, Van Dyck et ses élèves (Paris, 1882).

${ }^{41}$ Van den Branden, Antwerpsche schilderschool, 2:480.)This is no doubt due to his more traditional and severe style.

${ }^{42}$ Joseph Tricot-Royer was the first one to suggest this identification, on the basis of Westerhout's engraving, which he had discovered in Paris; see La Leçon d'Anatomie, 48. See also Didier Bodart, Loeuvre du graveur Arnold van Westerhout (1651-1725): Essai de catalogue raisonné (Brussels: Palais des Académies, 1974), 150, no. 607. In his last will, dated January 27, 1683, Joannes van Buyten designated "Francisco van Sterbeeck" to sell his library and paintings; see 
Duverger, Antwerpse kunstinventarissen, 11:200-201. For a brief biography of Van Buyten, see M. Boschmans, "Jan van Buyten: Een XVIIde-eeuwse Lierse medicus," 't Land van Ryen 8, 4 (1958): 175-81.

${ }^{43}$ Duverger, Antwerpse kunstinventarissen, 11:201: "Item van de Contrefeytselen ende van de Conversatie van Biseth"; although from the formulation it is not clear if "van Biseth" (of Biset) applies only to the conversation piece.

${ }^{44}$ SAA, GA 4077, f. 32. See also Dr. Van Schevensteen, "Het archief van het Chirurgijns- en Barbiersambacht," Antwerpsch Archievenblad (1926): 40. The rules are paraphrased by A. de Mets, Iconographie médicale anversoise, 9-10.

${ }^{45}$ See F. H. Mertens and K. L. Torfs, Geschiedenis van Antwerpen sedert de stichting der stad tot onze tijden (Antwerp, 1851), 6:190; C. Broeckx, Levensschets van Doctor Lazarus Marcquis, geneesheer en vriend van P.P.Rubens (n.p., 1854), 27-31. In the city archives of Antwerp, the Collegium Medicum has its own documents (SAA, GA 4513-4516) apart from the Corporation of Surgeons (SAA, GA 4077-4080).

${ }^{46}$ Compare, for instance, the many images of seventeenth-century Flemish portraits in Katlijne Van der Stighelen, Hoofd en Bijzaak: Portretkunst in Vlaanderen van 1420 tot nu (Leuven: Davidsfonds, 2008), 95-193, where sitters of different social rank show up next to one another.

${ }^{47}$ See, for instance, De Poorter, "De kunstwerken," 135.

${ }^{48}$ De geneeskunde in de Zuidelijke Nederlanden (1475-1660), exh. cat. (Antwerp: Museum Plantin-Moretus - Stedelijk Prentenkabinet, 1990), 255; Geneeskunde rond Rubens, 93.

${ }^{49}$ For an illustration, see De Poorter,"De kunstwerken," fig. 3.

${ }^{50} \mathrm{~A}$. de Mets, Iconographie médicale anversoise, 22, where the deans of the Antwerp Corporation of Surgeons are listed by year of function.

${ }^{51}$ See respectively, Hans Vlieghe, Stedelijke Musea Brugge: Catalogus schilderijen; $17^{\text {de }}$ en

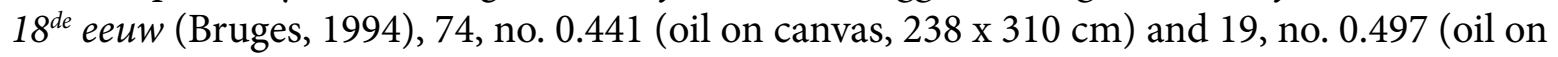
canvas, $109 \times 133 \mathrm{~cm}$ ).

${ }^{52}$ Middelkoop and Jurjens, "Kunsthistorische aspecten van de vier Delftse anatomische lessen," 67-71, fig. 61.

${ }^{53}$ See Norbert E. Middelkoop, "'Large and Magnificent Paintings, All Pertaining to the Chirurgeon's Art': The Art Collection of the Amsterdam Surgeons' Guild," in Rembrandt under the Scalpel: The Anatomy Lesson of Dr Nicolaes Tulp Dissected, exh. cat. (Amsterdam: Six Art Promotion BV, 1998), 20, fig. 12.

${ }^{54}$ See, for instance, A. de Mets, Iconographie médicale anversoise, 9; they are not mentioned, however, in R. Van Hee, "De chirurgie in de Zuidelijke Nederlanden (1475-1660)," in De geneeskunde in de Zuidelijke Nederlanden (1475-1660), exh. cat. (Antwerp: Museum Plantin-Moretus - Stedelijk Prentenkabinet, 1990), 19-36.

${ }^{55}$ See A. de Mets, Iconographie médicale anversoise, 9, on the basis of the request to the city of 16/03/1612 (SAA, PK 701, f. 233 r-v), and the Actum Collegii (SAA, T 21, f. 21v-22r).

${ }^{56}$ Hilde De Ridder-Symoens, "Marcquis (Marques), Lazarus," Nationaal Biografisch Woordenboek (Brussels: Paleis der Academiën, 1985), 11:480-84.

${ }^{57}$ See SAA, GA 4513, two requests of 1647, respectively: "ende hebbe van Mynheeren den Magistraet gesolliciteert ende geimpetreert de Anathomie camer, ende de reparatie van dien met den Theater, met groote moete[sic] gedirigeert, en met verscheede scheletons verciert"; "heeft by uwe Eerwaardighe gesoliciteert en verkregen de Anathomie camer op de nieu waghe en de selve bequaem doen maken tot publike exercitie des selve kunst: alwaer soo publieckelyc als privatelyck 
vele Anathomien geadministreert heeft".

${ }^{58}$ SAA, GA 4077, f. 36v, article 15: "tot profijt van dese kamere oft theater der Anatomie".

${ }^{59}$ Catalogue du Musée d'Anvers (Antwerp: Académie royale des beaux-arts, Conseil d'administration, 1874), 115.

${ }^{60}$ SAA, N 562 (Notary Jan Baptist Colijns), f. 39v. Published by Erik Duverger, Antwerpse kunstinventarissen, 5:415-16.

\section{Bibliography}

Beschrijvend catalogus: Oude Meesters; Koninklijk Muzeum voor Schoone Kunsten, vol. 1. Antwerp: Boucherij, 1905.

Bodart, Didier. L'oeuvre du graveur Arnold van Westerhout (1651-1725): Essai de catalogue raisonné. Brussels: Palais des Académies, 1974.

Boschmans, M. “Jan van Buyten: Een XVIIde-eeuwse Lierse medicus.” 't Land van Ryen 8, no. 4 (1958): 175-81.

Branden, Jos van den. Geschiedenis der Antwerpsche schilderschool. 3 vols. Antwerp: Buschmann, 1883.

Broeckx, C. Levensschets van Doctor Lazarus Marcquis, geneesheer en vriend van P.P. Rubens. N.p., 1854.

Catalogue du Musée d’Anvers. Antwerp: Buschmann, 1857.

Catalogue du Musée d'Anvers. Antwerp: Académie royale des beaux-arts, Conseil d'administration, 1874.

De geneeskunde in de Zuidelijke Nederlanden (1475-1660). Exh. cat. Antwerp: Museum Plantin-Moretus - Stedelijk Prentenkabinet, 1990.

Deschrevel, A. Schilderwerken van de Pseudo-Karel van Ieper (Frans Denys ?) en zijn school. Ieper, 1962.

Die Gemäldegalerie des Kunsthistorischen Museums in Wien: Verzeichnis der Gemälde. Vienna, 1991.

Duverger, Erik. Antwerpse kunstinventarissen uit de zeventiende eeuw. Vol. 5. Fontes Historiae Artis neerlandicae: Bronnen voor de kunstgeschiedenis van de Nederlanden. Brussels: Koninklijke Academie voor Wetenschappen, Letteren en Schone Kunsten van België, 1991.

Groeneweg, Irene. "Regenten in het zwart: vroom en deftig?” Nederlands Kunsthistorisch Jaarboek 46 (1995): 199-251. 
Hee, R. van “De chirurgie in de Zuidelijke Nederlanden (1475-1660).” In De geneeskunde in de Zuidelijke Nederlanden (1475-1660) (see above), 19-36.

Hollstein, F. W. H. Dutch and Flemish Etchings Engravings and Woodcuts ca. 1450-1700. Amsterdam: Menno Hertzberger, n.d.

Koninklijk Museum voor Schone Kunsten Antwerpen: Catalogus Schilderkunst Oude Meesters. Antwerp: Koninklijk Museum voor Schone Kunsten, 1988.

Mertens, F. H., and K. L. Torfs. Geschiedenis van Antwerpen sedert de stichting der stad tot onze tijden. Vol. 6. Antwerp: Buschmann, 1851.

Mets, Alexandre de. Iconographie médicale anversoise. Antwerp: Buschmann, 1929.

Michiels, Alfred. Van Dyck et ses élèves. Paris: Librairie Renouard, 1882.

Middelkoop, Norbert E. “'Large and Magnificent Paintings, All Pertaining to the Chirurgeon's Art': The Art Collection of the Amsterdam Surgeons' Guild.” In Rembrandt under the Scalpel: The Anatomy Lesson of Dr Nicolaes Tulp Dissected, 9-38. Exh. cat. Amsterdam: Six Art Promotion BV, 1998.

Middelkoop, Norbert, and Jeroen Jurjens. "Kunsthistorische aspecten van de vier Delftse anatomische lessen." In De snijkunst verbeeld: Delftse anatomische lessen nader belicht, 65-83. Edited by Hans Houtzager and Michiel Jonker. Zwolle: Waanders, 2002.

Mol, J. B. van. Anvers [Guide]: Histoire, Institutions, Description des Monuments et Oeuvres-d'Art. Antwerp : Chez l'auteur, [1874].

Musée national du Château de Versailles: Les peintures. Vol. 1. Paris, 1995.

Piot, Ch. Rapport à Mr. le Ministre de l'Intérieur sur les tableaux enlevés à la Belgique en 1794 et restitués en 1815. Brussels, 1883. Reprint, Algemeen Rijksarchief en Rijksarchief in de Provinciën, 1996.

Poorter, Nora de. "De kunstwerken van het Antwerpse barbiers-en chirurgijnsambacht." In Liber memorialis: 350 jaar Collegium Medicum Antverpiense, 25 jaar Geneeskundige Dagen van Antwerpen, 123-152. Antwerp: Koninklijke Geneeskundige Kring van Antwerpen, 1970.

Ridder-Symoens, Hilde de. "Marcquis (Marques), Lazarus." In Nationaal Biografisch Woordenboek, 11:480-84. Brussels: Paleis der Academiën, 1985.

Rooses, Max. Geschiedenis der Antwerpsche schilderschool. Gent: Hoste, 1879.

Schevensteen, Dr. van. "Het archief van het Chirurgijns- en Barbiersambacht." Antwerpsch Archievenblad (1926): 40. 
Speth-Holterhoff, S. “Un portraitiste oublié: Frans Denys.” Le cahier des Arts (June 1962): 2770-75.

Spilbeeck, Désiré van. "Hubertus Sporckmans." De Vlaamsche School 22 (1876): 190-191.

Spilbeeck, Désiré van. “Toestand van het Antwerpsch museum, in den zomer van 1868." De Vlaamsche School (1868): 192-202.

Stighelen, Katlijne van der. "Das Porträt zwischen 1550 und 1650: Die Emanzipation eines Genres." In Von Bruegel bis Rubens: Das goldene Jahrhundert der flämischen Malerei, 171182. Exh. cat. Edited by Ekkehard Mai and Hans Vlieghe. Cologne and Vienna, 1992/93.

Stighelen, Katlijne van der. Hoofd en Bijzaak: Portretkunst in Vlaanderen van 1420 tot nu. Leuven: Davidsfonds, 2008.

Tricot, Jean-Pierre. "De Les in de Ontleedkunde van Antwerpen (1660): Hubertus Sporckmans (1619-1690).” In Geneeskunde rond Rubens, 71-76. Exh. cat. Antwerp: Mercurius, 1977.

Tricot-Royer, Joseph. "La Leçon d'Anatomie d'Anvers." Bulletijn der Belgische vereeniging voor Geschiedenis der Geneeskunde 1 (1923): 40-50.

Tricot-Royer, Joseph. L’amphithéâtre anatomique d’Anvers en 1660. Antwerp: De Vlijt, 1923.

Vlieghe, Hans. Flemish Art and Architecture 1585-1700. New Haven and London: Yale University Press, 1998.

Vlieghe, Hans. Stedelijke Musea Brugge: Catalogus schilderijen; $17^{\text {de }}$ en $18^{\text {de }}$ eeuw. Bruges, 1994.

\section{Archival Sources}

SAA (Stadsarchief Antwerpen)

GA (Gilden en Ambachten)

Barbiers en Chirurgijns (Barbers and Surgeons)

GA 4077 (1454-1787); GA 4080 (1615-1723)

Collegium Medicum

GA 4513 ([1499]-18 ${ }^{\text {th }}$ century); GA $4514\left(17^{\text {th }}-18^{\text {th }}\right.$ century)

$\mathrm{N}$ (Notariaat) 562

Contract before notary Jan Baptist Colijns, February 3, 1648

PK (Privilegiekamer) 3579

Nota's Van den Branden

\section{Recommended Citation:}

